\title{
Promoting Gender Equality, SDG5 in Gymnastics
}

\author{
M$^{\mathrm{a}}$ Alejandra Ávalos-Ramos ${ }^{1}$, Gladys Merma-Molina ${ }^{1}$, Lilyan Vega-Ramirez ${ }^{1}$ \\ ${ }^{1}$ Departament of General and Specific Didactic, Education Faculty, University of Alicante, Alicante, Spain \\ Correspondence: Máalejandra Ávalos-Ramos, Departament of General and Specific Didactic, Education Faculty, \\ University of Alicante, Alicante, Spain.
}

Received: Mar. 5, 2020

Accepted: Mar. 22, 2020

Online Published: Mar. 26, 2020

doi:10.11114/ijce.v3i1.4790

URL: https://doi.org/10.11114/ijce.v3i1.4790

\begin{abstract}
The training of future teachers of Physical Activity and Sport Sciences (PAS) must offer learning that ensures comprehensive training. The social demand and the international call to achieve global objectives to overcome any problems associated with health, education or gender differences, makes training and awareness approach necessary for these future professionals. This area, where Olympic values such as respect, excellence and friendship are paramount, has much to offer in addressing these issues. Gender differences in spaces that are still masculinized such as the sports world are a worrying issue; within sports disciplines, the various gymnastic specialties are a traditional area from which to contribute. The aim of this study is to identify the prior knowledge of PAS students in relation to the Sustainable Development Goals (SDGs) and to implement and assess a teaching action to contribute to the specific training of students on the SDGs and specifically on SDG5: Gender Equality. This way, the teaching strategy has contributed to the awareness of university students towards these objectives and goals, to the identification and description of the main initiatives from the Royal Spanish Gymnastics Federation (RFEG) associated with the development of SDG 5, as well as to the design of possible actions to reduce gender differences and inequalities in the gymnastic environment.
\end{abstract}

Keywords: teaching strategy, inequalities, university students, gymnastics, sustainable development goals

\section{Introduction}

Despite the importance of sport for people's well-being and health, progress in incorporating women in this field has been slow and late (Fernández \& López, 2012; Marugán, 2019). This process has taken place in three stages. At first, the objective was to quantitatively increase the participation of women and girls in sports practices; later, the idea was to break sexist stereotypes in sport and, in a third stage, attempts are being made to eliminate the artificial separation between sports for men and women (Clayton \& Humberstone, 2006); however, there is still resistance and prejudice, even in the basic conceptions of sports policies in European countries (Dosal, Mejía, \& Capdevilla, 2017). Patterns and predictors of physical activity are clearly influenced by gender, and women have lower levels of physical activity and leisure-time exercise than men (Crespo-Salgado, Delgado-Martín, Blanco-Iglesias, \& Aldecoa-Landesa, 2015; González $\&$ Rivas, 2018). In this line, the Women and Sports Foundation (WSSF, 2010) maintains that girls are less prone to sport than boys. In addition, only a quarter of them do 60 minutes of physical activity per day, a proportion that decreases after the age of 10 . Low female participation continues into adulthood and only $12.7 \%$ of people over 16 years old practice sport at least once a week.

According to the National Institute of Statistics (2019) with data collected in the National Health Survey (2017) the percentage of sedentary people in Spain is $30.2 \%$ in the population group of 15 and 16 years old, being higher in women than in men, with a difference of $14 \%$. Women have always been more reluctant to do anything related to sport. As stated by the Spanish Sports Council, the practice of sport by girls aged between 16 and 18, in 2017, has fallen to 20 points compared to those aged 6 and 7 (Ministry of Culture and Sport, 2017). This phenomenon is more alarming when compared to boys, since it reaches a difference of 30 points.

Therefore, gender differences in the world of sport continue to be an issue of concern and reflect the prevalence of a patriarchal culture (Monforte \& Úbeda-Colomer, 2019). In particular, gymnastics, and especially some of its modalities, such as rhythmic gymnastics, are still conceived as a particularly female sport (Pfister, 2010), which has been traditionally reflected, for decades, in the literature of the specialty. Burstyn (1999) considers gymnastics to be hyper-feminine and O'Farril (1982) argues that rhythmic gymnastics helps women to develop their physical and psychological capacities and contributes to femininity, rhythm, grace in movements and that it also contributes 
positively to aesthetic education and defends that it is a sport created specifically for women. However, the configuration of sport today and of our society means that not only women are affected by sexism, but other groups, including men, are influenced by traditional stereotypes and roles based on the patriarchal culture. Patriarchal supremacy on the sports field, according to Hargreaves (2003), is more resistant to change than in other areas, has not only oppressed women, but has marginalized many men (Piedra, 2017; Tischler \& McCaughty, 2011) who did not conform to the patterns of hegemonic masculinity (Connell \& Messerchmidt, 2005). In a recent study, Gallardo (2019) concludes that gymnastics specialties', such as rhythmic gymnastics, still need to be improved, and for this it is necessary to integrate inclusive education at school age and develop training courses on equality in sport for teachers and parents from the sports federations. Given this tradition of gymnastics, the school could be an appropriate setting to work with gender perspective. And if educational action goes hand in hand with official institutions, such as gymnastics sports federations, the success could be even greater. For this, it is necessary that these develop an institutional culture and norms of identification that go beyond external symbols, that become codes of behavior and forms of participation and coexistence.

A fundamental element in the reproduction and transformation of gender relations is the teacher (Sánchez-Hernández, Martos-García, \& Soler i Prat, 2018). Therefore, the training of future Physical Activity and Sport Sciences (PAS) teachers must offer learning that ensures comprehensive training. The social demand and the international call to achieve global objectives to overcome problems associated with gender differences, make it necessary to have a training and awareness approach for future Physical Education professionals. The Brighton Declaration (1994) reflects the decision of States to commit all efforts to ensure that sports institutions in each country take into account the rules of the United Nations Charter and the Universal Declaration of Human Rights, which sets out agreed regulations regarding women and sport, committing governments to make every effort to create conditions of equality in sport, expanding budgets and investments in facilities to increase women's participation, organizing children's and school sport to facilitate children's participation, ensuring equitable support for both genders, developing policies, programs and structures to increase the number of women in sports leadership positions, ensuring that resources are allocated to meet the needs of both genders, and increasing experience sharing and international cooperation in sport and gender equality.

Also, Agenda 2030 for Sustainable Development (UN, 2015) reaffirms the commitment of the international community to achieve gender equality and the empowerment of all women and girls through a specific goal (SDG 5). Wilfried Lemke (2016), Special Adviser to the UN Secretary-General on Sport for Development and Peace, argues that sport and physical activity can empower women and girls who can benefit from its positive effect on their health and psychosocial status.

Gender is a socio-cultural construct that affects both men and women, but throughout history women have suffered from the consequences of the cultural meaning that society has given them, such as discrimination, gender-based violence, harassment, intolerance and a set of negative and harmful social practices that cannot be allowed in the 21 st century. Gender equality is not only a fundamental human right, but also the necessary foundation for a more peaceful, prosperous and sustainable world, and it is therefore indisputably linked to education in all its facets, from access, within education (content, context and practices of teaching-learning, assessment) and in learning outcomes and opportunities for life and work (UNESCO, 2014).

The reality described above reveals the importance of integrating gender equality into teacher and research training for future physical education teachers. This training should aim, first of all, at the understanding and assumption of the students of the importance of eradicating gender as a dominant category in society and that equality is a human rights principle. The second objective is that the students' own daily relations and interactions should be based on the values of gender equality and equity, and finally that they should be able to integrate the gender perspective both in research and in future professional performance.

Within this framework, the aims of this study are:

1. To identify the prior knowledge of PAS students about SDGs.

2. To analyze what knowledge the PAS student body has about SDG5.

3. To recognize the actions of the Royal Spanish Gymnastics Federation associated with Gender Equality.

4. To design proposals for action by the SDG5 through PAS students.

\section{Method}

The qualitative approach for this case study has allowed us to analyze the perspective and knowledge of the participants in relation to SDG5 and its analysis from the sources of information offered by the RFEG. 


\subsection{Participants}

The participants belong to the first year of the Physical Activity and Sport Sciences Degree at a Spanish university. It should be noted that the presence of male students enrolled in this degree is greater than that of women, according to official registration data for the academic year 2019-2020. The total number of first-year students in the aforementioned degree is 110 , of which only 35 are women (31.8\%). Of the 110 students enrolled, 81 participated (61 men and 20 women), and these are the students who regularly attend theoretical classes in the subject of Gymnastic Skills.

\subsection{Procedure}

During the development of the subject of Gymnastic Skills a teaching proposal was carried out (6 hours) which consisted on dealing with the subject of SDGs related to the sport discipline of Gymnastics.

This teaching practice was made up of three phases:

1. Assessment of students' prior knowledge in writing and individually through the following open questions: What do you know about SDGs? And how would you define gender equality?

2. Once the information had been collected, the general and specific subject matter was explained and then an analysis of the RFEG website was proposed and the direct and indirect actions of this sports body were identified.

3. In the third phase, the students designed their own proposals for action so that the RFEG could contribute to the development of the SDG5.

These last two phases were carried out collaboratively and in pairs (39 pairs and a group of three students). This organization was mainly due to the interest of the teacher of the subject to promote cooperative teaching strategies. Likewise, the infrastructure of the classroom, which had 40 computers, was ideal for students to work with a colleague.

\subsection{Instrument and data analysis}

For the collection of data, the documents written by the students during the implementation of the classroom proposal were used, having obtained 80 documents that responded to previous knowledge on the subject. Likewise, 40 documents were collected that referred to the action proposals designed by each pair of students.

Subsequently, a first reading of the collected information was made and the information was categorized with an inductive analysis, a process in which three experts in the field of study participated. This process of selection and analysis of the emerging codes from the students' answers, and the framework of the study's objectives, shapes dialectic between the theoretical framework, the participants' perceptions and the researchers' knowledge of the context (Ávalos, Martínez, \& Merma, 2016). The program AQUAD 7 (Huber \& Gürtler, 2013) was used to organize and count the categories and codes. The results are presented with the Absolute Frequency (AF) and its corresponding percentage, where $\mathrm{AF}$ is the number of identified findings on a given concept.

\section{Results}

The main findings are presented in tables and with narratives taking into account the phases of the teaching proposal.

\subsection{Phase 1: SGDs and SGD 5 Pre-knowledge of PAS Students}

Most PAS students, as seen in Table 1, have no prior knowledge of SDGs. Only a small percentage comes close to understanding the meaning of SDGs. In this regard, two students present:

They are related to a series of goals that are set for the development or improvement of the planet (Student_09).

They are the objectives that are set for the sustainability of the environment, through goals and proposals that have an impact on time (Student_40).

Table 1. PAS students' pre-knowledge of SDGs

\begin{tabular}{llc}
\hline & $\mathrm{AF}$ & $\% \mathrm{AF}$ \\
\hline None & 74 & $91.35 \%$ \\
Yes & 7 & $8.65 \%$ \\
TOTAL & 81 & \\
\hline
\end{tabular}

Regarding their conception of gender equality (Table 2), students associate this objective mainly with equal rights $(29.9 \%)$, equal treatment $(24.5 \%)$ and equal opportunities between both sexes $(23.9 \%)$. Some definitions of the 
participants are:

By gender equality I mean having the same rights, opportunities, facilities and recognition for both men and women (Student_55).

That men and women have the same conditions when it comes to finding a job, studying, practicing sports and receiving a salary (Student_33).

By gender equality I understand that this is not a condition when it comes to granting acknowledgements, responding to obligations or the degree of respect one has for other people, among other things (Student_30).

Table 2. Concept of Gender Equality (SDG5) according to students

\begin{tabular}{lll}
\hline Codes & $\mathrm{AF}$ & $\% \mathrm{AF}$ \\
\hline Equal rights & 44 & $29.9 \%$ \\
Equal treatment & 36 & $24.5 \%$ \\
Equal opportunities & 35 & $23.9 \%$ \\
Equality of capacity & 14 & $9.5 \%$ \\
Equal obligations & 9 & $6.1 \%$ \\
Mutual respect & 9 & $6.1 \%$ \\
TOTAL & 147 & \\
\hline
\end{tabular}

In addition, although to a lesser extent, definitions emerge from SDG 5 that refers to equality of capabilities (9.5\%), equality of obligations $(6.1 \%)$ and mutual respect $(6.1 \%)$. The following narratives represent these codifications:

I think it's showing the same respect and values for the same genders, whether it's male, female or however you want to define yourself. Both genders have to be valued equally so equality can exist (Student_15).

Gender equality is that situation that needs to be based on equity, respect and understanding. Currently this concept is making progress, but both genders need to work to balance the scales in different areas: salary, social and sports (Student_06).

\subsection{2nd Phase: The SDG5 in the Royal Spanish Gymnastics Federation}

In this block the direct (Table 3) and indirect actions identified by the students in this national sports organization are presented.

PAS students recognize five actions linked to SDG 5 in the Royal Spanish Gymnastics Federation. First, the Women and Sport Section (67.44\%). Three main actions are highlighted in this code: the Brighton Declaration (23.25\%), the Women and Sport programs, which also include a Guide to Incorporation in Sports Management and Gender Equality (20.93\%) and nine newsletters from 2016 to June 2019. Of these, the December 2018 and June 2019 bulletins are specifically identified (4.65\%). Finally, there is a third action in this block called Press \#WOMEN CHAMPION. "Spanish sportswomen fight for equality" (18.6\%).

Secondly, the Plan for Prevention and Action against Abuse, Harassment and Sexual Assault \#Three Times No (18.6\%) is highlighted, which REFEG includes on its website. Thirdly, they identify, to a lesser extent, the subsidies (5.81\%) that this body allocates to women; fourthly, they point out the existence of a strategic equality plan $(4.65 \%)$ and, finally, and with the least frequency of display, they mention the IBERDROLA Gymnastics League (3.5\%). 
Table 3. Direct RFEG actions contributing to the development of SDG 5

\begin{tabular}{lll}
\hline Codes & AF & $\% \mathrm{AF}$ \\
\hline 1.Women and sport section: & 58 & $67.44 \%$ \\
Brighton Declaration & 20 & $23.25 \%$ \\
Women and sports programs: & & \\
- Guide for incorporating equality in the management of sports federations & 18 & $20.93 \%$ \\
- Newsletters February 2016-June 2019 & 4 & $4.65 \%$ \\
Press \#WOMEN CHAMPION. "Spanish sportswomen fight for equality" & 16 & $18.6 \%$ \\
2.Abuse, Harassment and Sexual Assault Prevention and Response Plan & 16 & $18.6 \%$ \\
\#Three Times No & 5 & $5.81 \%$ \\
3.Grants for women & 4 & $4.65 \%$ \\
4.Organic Law 3/2007. Strategic equality plan & 3 & $3.5 \%$ \\
5.IBERDROLA League & 86 & \\
TOTAL & & \\
\hline
\end{tabular}

Students also observe some indirect actions related to the use of equal language and visual communication to disseminate the information on their website. They also highlight that some of the gymnastic disciplines collected are disaggregated by gender and in mixed competition categories. Five pairs of students pointed out these findings.

\subsection{Phase 3: Proposals for Action to Contribute to the Development of SDG 5 from RFEG}

The main proposals made by the students to promote the development of gender equality from the gymnastics federation are shown in Table 4. Along these lines, specific conferences and talks (26.2\%) are proposed, aimed at both athletes and coaches as well as families, to address issues associated with gender equality. It is also valued that there are mixed categories and competitions in all gymnastic modalities (21.4\%). On the other hand, it is suggested that Law 3/2007 must be taken into account for control, complaints and penalties (21.4\%) in cases of abuse and inequality in any of its manifestations. Likewise, the students expressed the importance of designing a plan to promote equality in salaries, resources and sports awards (16.7\%). Finally, there are proposals associated with promoting a greater presence of women athletes in the media (14.3\%).

Table 4. Main proposals of the students for the development of the SDG 5 in the Gymnastic disciplines

\begin{tabular}{lll}
\hline Codes & AF & $\% \mathrm{AF}$ \\
\hline Conferences, talks, campaigns & 11 & $26.2 \%$ \\
Mixed categories and mixed sport competitions & 9 & $21.4 \%$ \\
Control, denounce and penalize inequalities based on the law 3/2007 & 9 & $21.4 \%$ \\
Plan to equalize salaries, resources, sports awards & 7 & $16.7 \%$ \\
Increased visibility and more interviews with sportswomen in the media & 6 & $14.3 \%$ \\
TOTAL & 42 & \\
\hline
\end{tabular}

\section{Discussion and Conclusions}

The aim of this study was to implement and analyze a teaching action to first year PAS students associated with the development and knowledge of the SDGs and, specifically, to the SDG5 linking it with the sports gymnastic field.

Despite policies implemented in the European and Spanish context since 2015, the study's key findings show that most PAS students have no prior knowledge of SDGs. This reality requires a reflection on how they are being addressed in educational policies for Secondary and Higher Education in Spain, with respect to the development of Agenda 2030. Since the SDGs are an important social and political commitment to achieve sustainable development of countries, it is crucial that educational institutions, as transformers of social reality, become involved in these tasks by integrating these objectives in a systematic, structural manner. 
Gender equality is translated as a basic right that influences all areas of human development and its scope is fundamental in all spheres, especially in labor, social, educational, political, and sports; therefore, its inclusion and discussion of a transversal, explicit and undiluted nature (Serra et al., 2018), is essential in the university training of Physical Activity and Sport Sciences. PAS students are aware of this, but they do not yet have enough knowledge and skills to integrate these values into both their daily relationships and future professional performance, even less so in stereotypical sports such as gymnastics.

Gymnastics is still recognized as a sport for women and men who show female traits or who perform female activities (Fadzal \& Chung, 2018), so it is necessary for the various institutions linked to this sport, such as PAS races and sports federations, to promote changes towards equality.

In spite of the actions that the RFEG proposes to promote gender equality, such as having a Women and Sport Section, a Plan for the prevention and action against abuse, harassment and sexual aggression, \#Three Times No, with economic subsidies aimed at women athletes or with a strategic equality plan, in general there is still a less visible and less recognized space in women's sport, especially in the media; according to Macharia (2015) only $13 \%$ of European sports news is from women. In Spain the problem is more accentuated since women athletes only have $2.25 \%$ of the television space in relation to men (Vega \& Ávalos, 2016).

Likewise, equality in sport management the RFEG has a Guide to incorporate equality in the management of sport federations; these actions that can bring small achievements towards equality but the data still indicate that the presence of women in management or executive positions is scarce. The representation of women in the governing bodies of Spanish federations, in general assemblies, delegated commissions, boards of directors, or committees of judges only constitutes 16\% (Sport Council of Spain, 2015). In the case of the RFEG, women in the governing bodies have a representation of $31 \%$.

It should be noted that the proposals and recommendations made by students to improve the incorporation of SDG5 into the RFEG, coincide with the proposals of other studies carried out recently (e.g., Piedra, 2018). These are related to the organization of talks and conferences and the promotion of mixed sports competitions in an area such as rhythmic gymnastics, where, although a greater male presence has been achieved, traditional stereotypes relating to femininity, beauty and aesthetics still exist (O'Farril, 1982).

Despite the fact that many of the gymnastic disciplines included in the RFEG have a mixed competition mode, for example Acrobatic Gymnastics, the students who participated in the study consider it very important to continue promoting this type of competition from the lower categories and at different performance levels. Proposals such as that put forward by Orts (2018) with regard to school competition should structure competitions in categories by level, and not by sex, in accordance with the education system and/or adapt the corresponding regulations, all of which could contribute to making sport more egalitarian at all stages and levels.

In Spain, the Organic Law 3/2007 of March 22nd for the Effective Equality of Women and Men is a fundamental tool for institutions, trainers, athletes and families to control and report situations of discrimination in sport. The participants in the study are aware of its existence and demand its use when necessary, as advocated by the RFEG (2020).

From the experience carried out in this study it can also be inferred that, if in the configuration of the attitudes of teachers and their corresponding performance, the process of professional socialization plays a relevant role, which begins already in the previous experiences in the sport practice and continues in the daily professional development (Armour \& Jones, 1998; Devís, Martos, \& Sparkes, 2010), it is essential the implementation of strategies in the initial formation of the teachers of Physical Education. These must be based on reflection and analysis of gender issues using critical collaborative and co-educational methodologies (Lleixà, Soler, \& Serra, 2020), contributing to deepen, in the future professionals of sport, equality and equity.

In sum, gender-sensitive training of future PAS professionals, as reflected in the current literature and regulations, is a necessity and a requirement for the development of the school, sports activity, and society, and is a way to transform traditional gender models and relations.

\section{References}

Armour, K., \& Jones, R. (1998). Physical education teachers' lives and careers: PE, sport and educational status. London: Falmer Press.

Ávalos, M. A., Martínez, M. A., \& Merma, G. (2016). Gymnastics dispositions and skills: A case study listening to the voices of teachers. Science of Gymnastics Journal, 8(1), 57-70.

Brighton plus Helsinki Declaration 2014. Retrieved from https://iwgwomenandsport.org/es/brighton-declaration/ 
Burstyn, V. (1999). The rites of men. Manhood, politics, and the culture of sport. Toronto: University of Toronto Press. https://doi.org/10.3138/9781442682214

Clayton, B., \& Humberstone, B. (2006). Mens talk: A (pro)feminist, analysis male university football players discourse. International Review for the Sociology of Sport, 41(3-4), 295-316. https://doi.org/10.1177/1012690207078380

Connell, R. W., \& Messerschmidt, J. W. (2005). Hegemonic masculinity: Rethinking the concept. Gender \& Society, 19(6), 829-859. https://doi.org/10.1177/0891243205278639

Crespo-Salgado, J. J., Delgado-Martín, J. L., Blanco-Iglesias, O., \& Aldecoa-Landesa, S. (2015). Basic guidelines for detecting sedentarism and recommendations for physical activity in primary care. Atencion Primaria, 47(3), 175-183. https://doi.org/10.1016/j.aprim.2014.09.004

Devís, J., Martos, D., \& Sparkes, A. (2010). Socialización y proceso de construcción de la identidad profesional del educador físico de una prisión. Revista de Psicología del Deporte, 19(1), 73-88.

Dosal, R., Mejía, P., \& Capdevila, L. (2017). Deporte y equidad de género. Economía UNAM, 14(40), 121-133. https://doi.org/10.1016/j.eunam.2017.01.005

Fadzal, I. N., \& Chung, H. (2018). Overcoming the stereotypes of masculinity in Singaporean elite level male gymnasts. The Asian Journal of Kinesiology, 20(4), 30-42. https://doi.org/10.15758/ajk.2018.20.4.30

Fernández, M. A., \& López, C. (2012). La participación de las mujeres en el deporte: Un análisis desde la perspectiva de género. I Ciclo Conferencias Xénero, Actividad Física e Deport. Retrieved from https://ruc.udc.es/dspace/bitstream/handle/2183/9078/ActasGEXAFD3.pdf

Gallardo, D. (2019). Análisis de las masculinidades en la Gimnasia Rítmica: la visión de gimnastas, familias y entrenadoras (Tesis de Fin de Grado). Sevilla: Universidad de Sevilla.

González, N. F., \& Rivas, A. D. (2018). Actividad física y ejercicio en la mujer. Revista Colombiana de Cardiología, 25, 125-131. https://doi.org/10.1016/j.rccar.2017.12.008

Hargreaves, J. (2003): Sporting females. Critical issues in the history and sociology of women's sports. London and New York: Routledge. https://doi.org/10.4324/9780203221945

Huber, G. L., \& Gürtler, L. (2013). AQUAD 7. Manual del programa para analizar datos cualitativos. Tübingen: Günter Huber.

Lemke, W. (2016). El papel del deporte en la consecución de los Objetivos de Desarrollo Sostenible. Crónica ONU 53(2).

Retrieved

from https://unchronicle.un.org/es/article/el-papel-del-deporte-en-la-consecuci-n-de-los-objetivos-de-desarrollo-sostenib le

Lleixà, T., Soler, S., \& Serra, P. (2020). Perspectiva de género en la formación de maestras y maestros de Educación Física. Retos: Nuevas Tendencias en Educación Física, Deporte y Recreación, (37), 634-642.

Macharia, S. (2015). Who makes the news? Global media monitoring project 2015. London: World Association for Christian Communication.

Marugán, B. (2019). Análisis sociológico del deporte femenino. Sociological Analysis of female sports. In B. Marugán (Ed.), El deporte femenino, ese gran desconocido (pp. 45-68). Madrid: Universidad Carlos III de Madrid.

Ministry of Culture and Sport (2017). Anuario de estadisticas deportivas. Retrieved from http://www.culturaydeporte.gob.es/servicios-al ciudadano/estadisticas/deportes/anuario-de-estadisticas-deportivas.html

Monforte, J., \& Úbeda-Colomer, J. (2019). 'Como una chica': Un estudio provocativo sobre estereotipos de género en Educación Física ('Like a girl': A provocative study on gender stereotypes in Physical Education). Retos, 36(36), 74-79. Retrieved from https://recyt.fecyt.es/index.php/retos/article/view /68598

National Statistics Institute (2019). Encuesta Nacional de Salud de España 2017. Retrieved from https://www.mscbs.gob.es/estadEstudios/estadisticas/encuestaNacional/encuesta2017.htm

O’Farril, A. (1982). Gimnasia Rítmica Deportiva. La Habana: Pueblo y Educación.

Orts, F. (2018). La co-educación en el deporte escolar. Actividad Física y Deporte: Ciencia y Profesión, (29), 9-33.

Pfister, G. (2010). Women in sport-gender relations and future perspectives. Sport in Society, 13(2), 234-248. https://doi.org/10.1080/17430430903522954

Piedra, J. (2017). Masculinity and rhythmic gymnastics. An exploration on the transgression of gender order in 
sport. Masculinities \& Social Change, 6(3), 288-303. https://doi.org/10.17583/mcs.2017.2733

Real Federación Española de Gimnasia (2020). Retrieved from http://rfegimnasia.es/gobierno

Real Federación Española de Gimnasia (2020). Retrieved from http://rfegimnasia.es/mujer

Sánchez-Hernández, N., Martos-García, D., \& Soler i Prat, S. S. (2019). La (re)construcción de la identidad profesional de las profesoras de EF: de la complicidad y la reproducción de las relaciones de género a la disposición al cambio educativo. Revista Complutense de Educación, 30(3), 879-893. https://doi.org/10.5209/rced.59504

Serra, P., Soler, S., Prat, M., Vizcarra, M. T., Garay, B., \& Flintoof, A. (2018). The (in)visibility of gender knowledge in the Physical Activity and Sport Science degree in Spain. Sport, Education and Society, 23(4), 324-338. https://doi.org/10.1080/13573322.2016.1199016

Superior Sports Council (2015). Resumen datos estadísticos de la Memoria de 2015. Deporte federado y de alta competición. In line: http://www.csd.gob.es/csd/estaticos/ asoc-fed/2015-1.Resumen_General.pdf (accessed 13 January 2020).

Tischler, A., \& McCaughtry, N. (2011). PE is not for me: when boys' masculinities are threatened. Research Quarterly for Exercise and Sport, 82(1), 37-48. https://doi.org/10.1080/02701367.2011.10599720

UNESCO (2014). Plan de acción de la UNESCO para la prioridad "Igualdad de género" 2014-2021. Documentos estratégicos complementarios del 37 C/4 y el 37 C/5. Organización de las Naciones Unidas para la Educación, la Ciencia y la Cultura.

United Nations (2015). Nueva agenda para el desarrollo sostenible. Retrieved from https://www.un.org/sustainabledevelopment/es/objetivos-de-desarrollo-sostenible/

Vega, L. \& Ávalos, M. A. (2016). La presencia de la mujer deportista en la televisión. Feminismo/s, 27, 165-175. https://doi.org/10.14198/fem.2016.27.09

WSSF (2010). Young Women and Girls Sport and Physical Activity. London.

\section{Copyrights}

Copyright for this article is retained by the author(s), with first publication rights granted to the journal.

This is an open-access article distributed under the terms and conditions of the Creative Commons Attribution license which permits unrestricted use, distribution, and reproduction in any medium, provided the original work is properly cited. 